\title{
ANALISIS YURIDIS WEWENANG PEMERINTAHAN PUSAT DAN PEMERINTAHAN DAERAH DALAM PENGURUSAN TANAH DI INDONESIA
}

\author{
Hasiah \\ Institut Agama Islam Sultan Muhammad Syafiuddin Sambas \\ e-mail: Hasiahrasyida@gmail.com
}

\begin{abstract}
This research is a study of the relationship between the central and regional governments related to land management in Indonesia based on juridical analysis. The theoretical basis used is according to Herbert G. Hick, which states that authority is the right to do something and is a legitimate source of power. Therefore, the authority of the central government and local governments is based on the applicable legality principle.

The principle of legality referred to in land management is based on Law Number 23 of 2014 concerning regional governance, Basic Agrarian Law Law No.5 of 1960 (UUPA), Presidential Regulation (Perpres) of the Republic of Indonesia Number 20 of 2015 concerning the National Land Agency. (BPN), Presidential Regulation (Perpres) Number 148 of 2015 concerning Implementation of Land Acquisition for Development for Public Interest. From these laws and regulations, it can be concluded that the relationship between land management cannot be separated from the principle of decentralization. In Law No. 23/2014 there are also (3) sub-management of land that has no authority with the central government in matters of customary land, vacant land and the issuance of permits that are fully submitted to the Regional Government.

Based on the study of State Administrative Law, licensing matters in managing land are delegated to the Regency government (Governor or Regent) or the Regional Land Agency in order to review the smoothness and efficiency of time while in carrying out the functions carried out by the National Land Agency, namely by the central government as regulated in a Presidential Regulation No 20 of 2015, the scope of land affairs regulated in Law No. 23 of 2014 is relatively narrower than in Presidential Regulation 20 of 2015.
\end{abstract}

Keywords: Central Government, regional government, land management

\section{ABSTRAK}

Penelitian ini merupakan kajian hubungan pemerintah pusat dan daerah terkait pengurusan tanah di Indonesia berdasarkan telaah yuridis. Adapun dasar teori yang digunakan adalah menurut Herbert 
G.Hick yang menyebutkan wewenang adalah adalah hak untuk melakukan suatu hal dan merupakan sumber kekuasaan yang sah. Oleh sebab itu, maka wewenang dari pemerintah pusat dan pemerintah daerah yang berdasarkan atas asas legalitas yang berlaku.

Asas legalitas yang dimaksud dalam pengurusan tanah adalah berdasarkan UU Nomor 23 Tahun 2014 tentang pemerintahan daerah, Undang-Undang Pokok Agraria Undang-Undang No.5 Tahun 1960 (UUPA), Peraturan Presiden (Perpres) Republik Indonesia Nomor 20 Tahun 2015 Tentang Badan Pertanahan Nasional (BPN), Peraturan Presiden (Perpres) Nomor 148 Tahun 2015 tentang Penyelenggaraan Pengadaan Tanah Bagi Pembangunan untuk Kepentingan Umum. Dari peraturan perundang-undangan tersebut dapat disimpulkan bahwa hubungan pengurusan tanah tidak lepas dari asas desentralisasi. Dalam UU No 23 Tahun 2014 pula terdapat (3) sub pengurusan tanah yang tidak ada kewenangannya pada pemerintah pusat dalam hal urusan tanah ulayat, tanah kosong dan penerbitan Izin yang diserahkan sepenuhnya kepada Pemerintahan Daerah.

Berdasarkan kajian Hukum Administrasi Negara, urusan perizinan dalam menguruskan tanah dilimpahkan kepada pemerintah Kabupaten (Gubernur atau Bupati) atau Badan Pertanahan Daerah dalam rangka meninjau kelancaran dan efesiensi waktu sedangkan dalam pelaksanaan fungsi yang dijalankan oleh Badan Pertanahan Nasional yaitu oleh pemerintah pusat sebagaimana diatur dalam Peraturan Presiden No 20 Tahun 2015 maka ruang lingkup urusan pertanahan yang diatur dalam Undang-Undang No 23 Tahun 2014 relatif lebih sempit dibandingkan dalam Peraturan Presiden 20 Tahun 2015.

Kata Kunci:Pemerintahan Pusat, Pemerintahan Daerah, Pengurusan Tanah

\section{PENDAHULUAN}

Dalam pemerintahan provinsi di Indonesia, setiap wilayah memiliki hak dan wewenang untuk mengatur urusan rumah tangganya masingmasing kecuali urusan absolut atau urusan nasional. Urusan-urusan yang diserahkan dalam rangka mencapai kesejahteraan sesuai keberagaman SDM dan SDA tiap daerah. Salah satu urusan yang diserahkan kepada pemerintah daerah adalah urusan atas tanah. (23 Tahun 2014)

Urusan tanah sudah diatur dalam UUD 1945 yang dibahas secara umum kemudian diatur secara rinci dalam Undang- Undang Pokok Agreria 
atau UPPA termasuk dalam PP, UU Pemerintah Daerah serta UU lainnya. Urusan pertanahan memiliki peran yang sangat penting terutama dari sisi ekonomi dan sosial daerah. Sebagai NKRI, kebebasan untuk mengatur dan mengurus pertanahan tidak boleh terlepas dari pemerintah pusat dan hukum nasional sehingga selalu ada hubungan regulasi diantaranya.

Meskipun pengurusan tanah telah diatur dalam instrumen nasional, masih banyak terjadi permasalahan terutama menyangkutan kepentingan dari berbagai pihak. Tidak hanya itu, terjadi tumpang tindih atas kewenangan dan kebijakan dalam pengelolaan tanah baik dari pemerintah pusat maupun daerah. Oleh sebab itu, perlu analisa secara yuridis memperjelas kewenangan pemerintah pusat dan daerah.

\section{METODE PENELITIAN}

Penelitian ini menggunakan jenis penelitian kepustakaan atau library Research. Adapun metode penelitian yang digunakan adalah penelitian normatif, yaitu penelitian yang mengacu terhadap bahan-bahan pustaka. Kemudian menganalisis Undang-Undang yang berkaitan dengan hal pertanahan di Indonesia.(Neong Muhajir, 2000).

Penelitian ini memandang sudut pandang sinkronisasi antar peraturan perundang-undangan yang memiliki hubungan termasuk dalam asas-asas hukum dalam memakai konsep heirarki. Bentuk analisa yang diapakai dalam penelitian ini yaitu deduktif deskritif yaitu menganalisa dari data data umum menjadi sebuah kesimpulan khsusus.

\section{PEMBAHASAN}

Adapun hubungan pemerintah pusat dan daerah yang berkaitan dalam mengurus Tanah tercantum dalam Undang-Undang yaitu:

\section{A. Undang-Undang No 23 Tahun 2014 tentang Pemerintahan Daerah}

Berdasarkan Undang-Undang yang mengatur pemerintah daerah terdapat dalam Undang-Undang Nomor 23 Tahun 2014 yang dalamnya 
terdapat batasan-batasan dalam negara kesatuan RI yakni ketentuanketentuan yang tidak boleh dilampaui atau diselenggarakan oleh daerah. Berdasarkan Pasal 9 disebutkan bahwa urusan Pemerintahan terdiri atas urusan pemerintahan absolut, urusan pemerintahan konkuren, dan urusan pemerintahan umum. Urusan pemerintahan absolut adalah urusan Pemerintahan yang sepenuhnya menjadi kewenangan Pemerintah Pusat. Sedangkan urusan pemerintahan konkuren adalah Urusan Pemerintahan yang dibagi antara Pemerintah Pusat dan Daerah provinsi dan Daerah kabupaten/kota. (Ilyas, 2015)

Berdasarkan Pasal 12 bahwa urusan tanah merupakan salah satu Urusan Pemerintahan konkuren dan lebih lanjut dalam Pasal 13 ayat (1) disebutkan bahwa Pembagian urusan pemerintahan konkuren antara Pemerintah Pusat dan Daerah provinsi serta Daerah kabupaten/kota didasarkan pada prinsip akuntabilitas, efisiensi, dan eksternalitas, serta kepentingan strategis nasional. Dijelaskan dalam Pasal 13 ayat (2) bahwa berdasarkan prinsip-prinsip yang disebutkan pada ayat (1) maka kriteria Urusan Pemerintahan yang menjadi kewenangan Pemerintah Pusat adalah : (23 Tahun 2014)

a. Urusan Pemerintahan yang lokasinya lintas Daerah provinsi atau lintas negara;

b. Urusan Pemerintahan yang penggunanya lintas Daerah provinsi atau lintas negara;

c. Urusan Pemerintahan yang manfaat atau dampak negatifnya lintas Daerah provinsi atau lintas negara;

d. Urusan Pemerintahan yang penggunaan sumber dayanya lebih efisien apabila dilakukan oleh Pemerintah Pusat; dan/atau

e. Urusan Pemerintahan yang peranannya strategis bagi kepentingan nasional.

Sedangkankan kriteria Urusan Pemerintahan yang menjadi kewenangan Daerah provinsi adalah: 
a. Urusan Pemerintahan yang lokasinya lintas Daerah kabupaten/kota;

b. Urusan Pemerintahan yang penggunanya lintas Daerah kabupaten/kota;

c. Urusan Pemerintahan yang manfaat atau dampak negatifnya lintas Daerah kabupaten/kota; dan/atau

d. Urusan Pemerintahan yang penggunaan sumber dayanya lebih efisien apabila dilakukan oleh Daerah Provinsi.

Serta kriteria Urusan Pemerintahan yang menjadi kewenangan Daerah kabupaten/kota adalah:

a. Urusan Pemerintahan yang lokasinya dalam Daerah kabupaten/kota;

b. Urusan Pemerintahan yang penggunanya dalam Daerah kabupaten/kota;

c. Urusan Pemerintahan yang manfaat atau dampak negatifnya hanya dalam Daerah kabupaten/kota; dan/atau

d. Urusan Pemerintahan yang penggunaan sumber dayanya lebih efisien apabila dilakukan oleh Daerah kabupaten/kota.

Tidak hanya itu, pada pasal 16 ayat (2) menjelaskan bahwa norma, standar, prosedur, dan kriteria sebagaimana dimaksud pada ayat (1) huruf a berupa ketentuan peraturan perundang-undangan yang ditetapkan oleh Pemerintah Pusat sebagai pedoman dalam penyelenggaraan urusan Pemerintahan Konkuren yang menjadi kewenangan Pemerintah Pusat dan yang menjadi kewenangan Daerah.

Dalam Pasal 11 ayat (2) pada huruf d menyebutkan tanah merupakan Urusan Pemerintahan Wajib yang tidak berkaitan dengan Pelayanan Dasar. Urusan pemerintahan yang wajib tersebut berarti urusan yang wajib diselanggarakan oleh semua daerah seperti mana yang telah dijelaskan dalam Undang-undang ini. 
Dalam pada huruf $\mathrm{J}$ mengenai pembagian urusan pemerintahan bidang pertanahan disebutkan ada 9 (Sembilan) sub urusan yang dibagi antara pemerintah pusat, daerah propinsi dan daerah kabupaten/kota. Kesembilan sub urusan tersebut terdiri atas;

1. Izin lokasi

2. Pengadaan tanah untuk kepentingan umum,

3. Sengketa tanah garapan

4. Ganti kerugian dan santunan tanah untuk pembangunan,

5. Subjek dan objek redistribusi tanah serta ganti kerugian tanah kelebihan tanah maksimum dan tanah absentee,

6. Tanah ulayat,

7. Tanah kosong,

8. izin membuka tanah, dan

9. penggunaan tanah.

Dari 9 sub urusan tersebut terdapat 3 sub urusan yang tidak ada kewenangannnya pada pemerintah pusat, yaitu urusan tanah ulayat, tanah kosong dan izin membuka tanah. Kewenangan penerbitan izin membuka tanah hanya ada pada pemerintah kabupaten/kota. Di samping itu Kewenangan pengadaan tanah untuk kepentingan umum hanya ada pada pemerintah pusat dan daerah propinsi.

Sedangkan dalam Undang-Undang No 23 Tahun 2014 juga menyebutkan secara lebih konkrit mengenai kewenangan penyelesaian sengketa tanah: (Santoso, 2016)

1) Penyelesaian sengketa tanah garapan,

2) Penyelsaian masalah ganti rugi dan santunan tanah untuk pembangunan, dan

3) Penyelesaian masalah tanah kosong.

Penyelesaian sengketa tanah garapan dan penyelesaian masalah ganti rugi tanah untuk pembangunan ada pada semua level pemerintahan, sedangan kewenangan penyelesaian masalah tanah 
kosong hanya ada pada level pemerintah propinsi dan pemerintah kabupaten/kota.

Penjelasan mengenai urusan pertanahan dalam yang dilampirkan dalam undang-undang ini sebagai berikut:

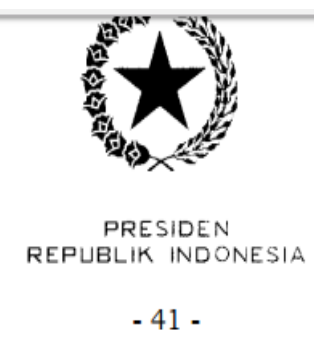

PEMBAgIAN URUSAN PEMERINTAHAN BIDANG PERTANAHAN

\begin{tabular}{|c|c|c|c|c|}
\hline NO & SUB URUSAN & PEMERINTAH PUSAT & DAERAH PROVINSI & $\begin{array}{c}\text { DAERAH } \\
\text { KABUPATEN / KOTA }\end{array}$ \\
\hline 1 & 2 & 3 & 4 & 5 \\
\hline 1. & Izin Lokasi & $\begin{array}{l}\text { Pemberian izin lokasi lintas } \\
\text { Daerah provinsi. }\end{array}$ & 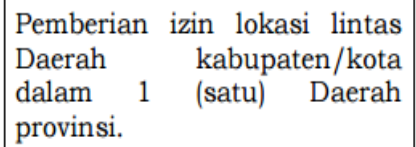 & $\begin{array}{l}\text { Pemberian izin lokasi dalam } \\
1 \quad \text { (satu) } \quad \text { Daerah } \\
\text { kabupaten/kota. }\end{array}$ \\
\hline 2. & $\begin{array}{lr}\text { Pengadaan } & \text { Tanah } \\
\text { Untuk } & \text { Kepentingan } \\
\text { Umum } & \end{array}$ & $\begin{array}{l}\text { Pelaksanaan pengadaan } \\
\text { tanah untuk kepentingan } \\
\text { umum. }\end{array}$ & $\begin{array}{l}\text { Penetapan lokasi pengadaan } \\
\text { tanah untuk kepentingan } \\
\text { umum provinsi. }\end{array}$ & $--\cdot$ \\
\hline 3. & $\begin{array}{l}\text { Sengketa } \\
\text { Garapan }\end{array}$ & $\begin{array}{l}\text { Penyelesaian sengketa tanah } \\
\text { garapan lintas Daerah } \\
\text { provinsi. }\end{array}$ & $\begin{array}{l}\text { Penyelesaian sengketa tanah } \\
\text { garapan lintas Daerah } \\
\text { kabupaten/kota dalam } 1 \\
\text { (satu) Daerah provinsi. }\end{array}$ & $\begin{array}{l}\text { Penyelesaian sengketa tanah } \\
\text { garapan dalam Daerah } \\
\text { kabupaten/kota. }\end{array}$ \\
\hline 4. & $\begin{array}{l}\text { Ganti Kerugian dan } \\
\text { Santunan Tanah Untuk } \\
\text { Pembangunan }\end{array}$ & $\begin{array}{l}\text { Penyelesaian masalah ganti } \\
\text { kerugian dan santunan } \\
\text { tanah untuk pembangunan } \\
\text { oleh Pemerintah Pusat. }\end{array}$ & $\begin{array}{l}\text { Penyelesaian masalah ganti } \\
\text { kerugian dan santunan tanah } \\
\text { untuk pembangunan oleh } \\
\text { Pemerintah Daerah provinsi. }\end{array}$ & $\begin{array}{l}\text { Penyelesaian masalah ganti } \\
\text { kerugian dan santunan } \\
\text { tanah untuk pembangunan } \\
\text { oleh Pemerintah Daerah }\end{array}$ \\
\hline
\end{tabular}




\begin{tabular}{|c|c|c|c|c|}
\hline No & SUB URUSAN & PEMERINTAH PUSAT & DAERAH PROVINSI & $\begin{array}{c}\text { DAERAH } \\
\text { KABUPATEN / KOTA }\end{array}$ \\
\hline \multirow[t]{2}{*}{1} & 2 & 3 & 4 & 5 \\
\hline & & & & kabupaten / kota. \\
\hline 5. & $\begin{array}{lr}\text { Subyek dan } & \text { Obyek } \\
\text { Redistribusi } & \text { Tanah, } \\
\text { serta Ganti } & \text { Kerugian } \\
\text { Tanah } & \text { Kelebihan } \\
\text { Maksimum dan } & \text { Tanah } \\
\text { Absentee } & \end{array}$ & $\begin{array}{l}\text { Penetapan subyek dan obyek } \\
\text { redistribusi tanah, serta } \\
\text { ganti kerugian tanah } \\
\text { kelebihan maksimum dan } \\
\text { tanah absentee lintas } \\
\text { Daerah provinsi. }\end{array}$ & 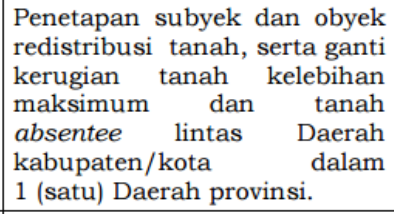 & $\begin{array}{l}\text { Penetapan subyek dan obyek } \\
\text { redistribusi tanah, serta } \\
\text { ganti kerugian tanah } \\
\text { kelebihan maksimum dan } \\
\text { tanah absentee dalam } \\
\text { Daerah kabupaten/kota. }\end{array}$ \\
\hline 6. & Tanah Ulayat & --- & $\begin{array}{l}\text { Penetapan tanah ulayat yang } \\
\text { lokasinya lintas Daerah } \\
\text { kabupaten/kota dalam } \\
1 \text { (satu) Daerah provinsi. }\end{array}$ & $\begin{array}{l}\text { Penetapan tanah ulayat yang } \\
\text { lokasinya dalam Daerah } \\
\text { kabupaten/kota. }\end{array}$ \\
\hline 7. & Tanah Kosong & -- & 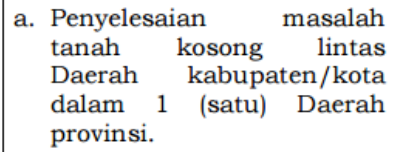 & $\begin{array}{l}\text { a. Penyelesaian masalah } \\
\text { tanah kosong dalam } \\
\text { Daerah kabupaten/kota. }\end{array}$ \\
\hline
\end{tabular}

\begin{tabular}{|c|c|c|c|c|}
\hline NO & SUB URUSAN & PEMERINTAH PUSAT & DAERAH PROVINSI & $\begin{array}{c}\text { DAERAH } \\
\text { KABUPATEN/KOTA }\end{array}$ \\
\hline \multirow[t]{2}{*}{1} & 2 & 3 & 4 & 5 \\
\hline & & & $\begin{array}{|lr|}\text { b. Inventarisasi } & \text { dan } \\
\text { pemanfaatan tanah } & \text { kosong } \\
\text { lintas } & \text { Daerah } \\
\text { kabupaten/kota } & \text { dalam } \\
1 \text { (satu) Daerah provinsi. }\end{array}$ & $\begin{array}{lr}\text { b. } \text { Inventarisasi } & \text { dan } \\
\text { pemanfaatan } & \text { tanah } \\
\text { kosong dalam } & \text { Daerah } \\
\text { kabupaten/kota. } & \end{array}$ \\
\hline 8. & Izin Membuka Tanah & $\cdots$ & $\cdots$ & $\begin{array}{l}\text { Penerbitan izin membuka } \\
\text { tanah. }\end{array}$ \\
\hline 9. & Penggunaan Tanah & $\begin{array}{l}\text { Perencanaan penggunaan } \\
\text { tanah yang hamparannya } \\
\text { lintas Daerah provinsi. }\end{array}$ & 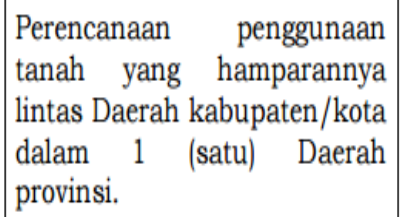 & $\begin{array}{lr}\text { Perencanaan penggunaan } \\
\text { tanah yang hamparannya } \\
\text { dalam } & \text { Daerah } \\
\text { kabupaten/kota. } & \end{array}$ \\
\hline
\end{tabular}

\section{B. Undang-Undang Pokok Agraria Undang-Undang No.5 Tahun 1960 (UUPA)}

Pengakuan bahwa seluruh bumi, air dan ruang angkasa, termasuk kekayaan alam yang terkandung di dalamnya dalam wilayah Republik Indonesia sebagai karunia Tuhan Yang Maha Esa, adalah bumi, air dan ruang angkasa Bangsa Indonesia dan merupakan kekayaan nasional yakni terdapat dalam ketentuan Pasal 1 ayat (2) UUPA). (Solihat, 2014). Dalam UUPA secara jelas dalam rangka melaksanakan UUD 1945 pada

Shar-E: Jurnal Kajian Ekonomi Hukum Syariah 
pasal 33 yakni bahwa bidang pertanahan merupakan wewenang pemerintah pusat. Namun dalam hal ini bukan berarti semua urusan pertanahan sepenuhnya pada pemerintah pusat, (Setiady, 2014) tetapi sebagai negara kesatuan dan tetap menjalankan otonomi atas dasar efesiensi dan efektivitas sebuah negara maka wewenang tersebut dilimpahkan sesuai asas desentralisasi.

Pernyataan ini terdapat dalam UUPA Pasal 2 ayat (4) yang menegaskan bahwa hak menguasai dari negara tersebut diatas pelaksanaannya dapat dikuasai oleh kepada daerah-daerah dan masyarakat-masyarakat hukum adat yang tidak bertentangan dengan kepentingan Nasional menurut Peraturan-Peraturan Pemerintah. (Santoso, 2016).

\section{Peraturan Presiden (Perpres) Republik Indonesia Nomor 20 Tahun 2015 Tentang Badan Pertanahan Nasional (BPN)}

Pada peraturan ini, urusan BPN diserahkan kepada menteri Agraria dan Tata Ruang. Untuk menyelenggarakannya, Peraturan Presiden yang konsisten yang didalamya memuat prinsip bahwa kewenangan bidang pertanahan berada pada pemerintah pusat, termasuk kewenangan penyelesaian sengketa pertanahan baik dalam lingkup nasional maupun daerah. Pelaksanaan kewenangan dibidang pertanahan oleh pemerintah daerah atas dasar pelimpahan kewenangan dan tugas pembantuan yakni melalui wilayah Kantor BPN Provinsi dan Kantor Pertanahan di Kabupaten / Kota. (PP No. 20 Tahun 2015 )

\section{Peraturan Presiden (Perpres) Nomor 148 Tahun 2015 tentang Penyelenggaraan Pengadaan Tanah Bagi Pembangunan untuk Kepentingan Umum}

Wewenang antara pemerintah Pusat dan pemerintah daerah dalam mengurus pertanahan telah disebutkan dalam Peraturan Presiden Nomor 
148 Tahun tentang Penyelenggaran Pengadaan Tanah Bagi Pembangunan Kepentingan Umum. Dalam pasal 1 ayat (1) menyebutkan instansi yang memerlukan tanah adalah lembaga negara, kementerian, lembaga pemerintah nonkementerian, pemerintah provinsi, pemerintah kabupaten/kota, dan Badan Hukum Milik Negara/Badan Usaha Milik Negara yang mendapat penugasan khusus Pemerintah atau Badan Usaha yang mendapatkan kuasa berdasarkan perjanjian dari lembaga negara, kementerian, lembaga pemerintah nonkementerian, pemerintah provinsi, pemerintah kabupaten/kota, dan Badan Hukum Milik Negara/Badan Usaha Milik Negara yang mendapat penugasan khusus Pemerintah dalam rangka penyediaan infrastruktur untuk kepentingan umum

Kejelasan mengenai hubungan pemerintahan pusat dan daerah bekerja sama dalam mengurus tanah juga terdapat pada ayat (7) bahwa Hak Pengelolaan adalah hak menguasai dari negara yang kewenangan pelaksanaannya sebagian dilimpahkan kepada pemegangnya. (Pepres No. 148 Tahun 2015 tentang Penyelenggaraan Pengadaan Tanah bagi Pembangunan untuk Kepentingan Umum). Pada pasal 1 ayat (19) dan (20) menyebutkan bahwa keberadaan Kantor Pertanahan merupakan instansi vertikal BPN di kabupaten/kota yang dipimpin oleh Kepala Kantor Pertanahan yang berada di bawah dan bertanggung jawab langsung kepada Menteri melalui Kepala Kantor Wilayah BPN. Persiapan pengadaan tanah yang selanjutnya disebut Tim Persiapan adalah tim yang dibentuk oleh gubernur untuk membantu gubernur dalam melaksanakan pemberitahuan rencana pembangunan, pendataan awal lokasi rencana pembangunan dan Konsultasi Publik rencana pembangunan.

Berdasarkan penjelasan di atas, bahwa pemerintah daerah atau gubernur didelegasikan untuk mengurus dan mengadakan tim pelaksanaan dan pengerjaan atas tanah yang dianggap memiliki 
kepentingan umum dalam rangka pembangunan daerah yang dipertanggung jawabkan kepada Menteri Agraria dan Tata Ruang Negara.

\section{E. Analisis Wewenang Pemerintah Pusat dan Pemerintah Daerah dalam Mengurus Tanah Menurut Undang-Undang Berlaku}

Menurut Herbert G.Hick, wewenang adalah hak untuk melakukan suatu hal dan merupakan sumber kekuasaan yang sah. (Anggriani, 2012). Wewenang suatu organisasi / badan atau individu diperoleh melalui pelimpahan kekuasaan. Begitu pula wewenang dari pemerintah pusat dan pemerintah daerah yang berdasarkan atas asas legalitas yang berlaku.

Sebagai negara kesatuan, hubungan wewenang tersebut bersumber dengan cara pelimpahan kekuasaan sehingga dalam membuat keputusan oleh pemerintah maka harus berdasarkan pada peraturan perundang-undangan formal yang terkait termasuk UU Pertanahan. Jadi bila keputusan atau peraturan tersebut telah dibuat maka memberikan kewajiban kepada rakyat secara keseluruhan termasuk daerah masing-masing. Hal tersebut disebabkan setiap wewenang yang ada pada pemerintah adalah berdampak hukum.

Pemerintah daerah diberikan kekuasaan memegang monopoli dengan batas-batas yang telah ditentukan dalam memanfatkan alamnya dan sebagai upaya mepertahankan hukum positif yang berlaku serta berpegang teguh pada ketatanegaraan yang herarki. Sebagai Badan yang bersifat hukum publik, maka Pemerintah Daerah dapat memanfaatkan tanah yang diperuntukan untuk umum atas dasar kepentingan bersama atau dalam rangka pembangunan. (Anggriani, 2012). Namun di dalam membuat Peraturan umum yang telah ditetapkan tidak boleh merugikan hak-hak orang lain dengan cara ganti rugi atau memberikan jaminan kesejahteraan bagi pemilik tanah. 
Pasal 33 ayat (3) 1945 yang telah disebutkan sebelumnya bahwa bumi dan kekayaan alam yang terkandung di dalamnya dikuasai oleh negara dan dipergunakan untuk sebesar-besar kemakmuran rakyat. Menguasai yang dimaksud dari negara dalam UUD tersebut yang diberi wewenang adalah untuk mengatur, pemeliharan, mengatur hubunganhubungan hukum yang berlaku dalam hal menguruskan tanah tanpa melanggar nilai-nilai keadilan termuat dalam UUD dan Pancasila. Berdasarkan Undang - Undang Dasar, maka ia merupakan hukum yang umum dan bersifat nasional dimana semua urusan bumi dan kekayaan alam yang ada dalam wilayah Negara Indonesia, dikuasai oleh Negara. Namun secara detil dalam pelaksanaanya terkait tanah terdapat dalam UU serta peraturan-peraturan pemerintah yang dijadikan standart untuk rujukan bagi pemerintah daerah. (Wignjosoebroto, 2013)

UU yang terkait dengan kewenangan di bidang pertanahan dalam UUPA yang telah dijelaskan sebelumnya. Pada Pasal 2 terdapat hukum tanah nasional dalam arti asasnya merupakan kewenangan pusat. Namun bentuk pelaksanaannya sebagai menjalankan Asas Pembantuan adalah dilakukan oleh pemerintah daerah karena urusan Tanah adalah bersifat lokal. Pelaksanaan asas tersebut adalah dalam rangka menyelenggarakan hukum tanah nasional.

Selanjutnya, menurut pasal 6 UUPA juga menyebutkan "semua hak ke atas tanah mempunyai fungsi sosial". Maksudnya adalah hak-hak perseorangan terhadap hak dari masyarakat sehingga jika ada suatu kepentingan dari masyarakat lebih tinggi, maka kepentingan perseorangan harus dikalahkan. Pasal tersebut juga terkait dengan Pasal 18 UUPA Pencabutan atas hak tanah diganti untuk kepentingan umum tetapi harus diberikan ganti rugi yang layak. (Anggriani, 2012)

Bila dikaitkan dengan Ilmu Hukum Admnistrasi Negara, Pemerintah adalah sebagai pemilik kepunyaan publik. Namun, dalam pelaksanaannya pemerintah mempunyai hak atas tanah sesuai 
peraturan Perundang-undangan yang tegas serta atas dasar unsur-unsur berkepentingan umum. Misalkan, kepentingan pembangunan, maka Presiden setelah mendengar Menteri Agreria atau BPN atau Menteri yang bersangkutan dan jika telah sesuai prosedur, maka pemerintah pusat memiliki kewenangan untuk mencabut kepemilikan serta benda-benda diatasnya dengan kerjasama pemerintah daerah. Namun jika pemilik tanah merasa dirugikan, maka dapat mengaju banding di Pengadilan terhadap negara serta menetapkan jumlah kerugian.

Pada UU No 23 Tahun 2014 pula terdapat (3) sub pengurusan tanah yang tidak ada kewenangannnya pada pemerintah pusat adalah urusan tanah ulayat, tanah kosong dan izin membuka tanah karena beberapa alasan sebagai berikut :

a. Urusan Tanah Ulayat

Urusan tanah ulayat memiliki tiga unsur yakni, adanya hak ulayat tertentu dan masyarakat hukum adat tertentu yang menjadi lingkaran hidup tempat mengambil keperluan hidup masyarakat tersebut, adanya tatanan hukum adat mengenai pengurusan, penguasaan dan penggunaan tanah ulayat oleh masyarakat adat. Hal tersebut tertuang dalam UPPA pasal 2. Oleh sebab itu, penentu keberadaan ulayat hanya dapat dilakukan oleh pemerintah daerah yang mengikut sertakan masyarakat adat maka hak yang diatur oleh Peratuan Daerah dan bidang-bidangnya tersendiri. (Mardjoyo, 2002)

Hal ini sebagai bentuk internalisasi status tanah-tanah Hak Ulayat ke dalam bentuk hukum yang diakui secara normatif dalam tata urutan perundang-undangan nasional sebagaimana diatur dalam UU No. 12 tahun 2011 tentang Pembentukan Peraturan Perundang-undangan. Pemerintah pembuatan perda perlu ditegaskan dalam RUU, agar status tanah ulayat mempunyai kedudukan dan bentuk hukum yang jelas dalam sistem hukum nasional agar manakala terjadi konflik yang melibatkan tanah ulayat, maka tanah 
ulayat mempunyai kedudukan hukum yang konkrit. Hal ini penting untuk memberikan kepastian hukum yang berkeadilan dan bermanfaat baik bagi MHA itu sendiri maupun bagi pemerintah. (Nurlinda, 2016)

b. Kewenangan Penerbitan Izin Membuka Tanah Hanya Ada Pada Pemerintah Kabupaten/Kota

Menurut Bagir Manan, izin dalam arti adanya persetujuan dari penguasa berdasarkan peraturan perundang-undangan untuk memperbolehkan perbuatan tertentu secara umum yang dilarang. Perizinan juga harus memenuhi unsur-unsur peraturan perundangundangan, organ pemerintah yang berkuasa, peristiwa atau konkret serta prosedur dan persyaratan.

Organ pemerintah dalam memberi izin menurut Hukum administrasi Negara adalah berdasarkan organ yang berwenang yang dilimpahkan dari Pejabat Adminitrasi tertinggi Negara (Presiden) melalui para Menteri sampai ke Pejabat Administrasi terbawah seperti Kepala Desa / Lurah. (HR, 2014). Oleh karena itu, secara yuridis dan UU, urusan perizinan dalam menguruskan tanah dilimpahkan kepada pemerintah Kabupaten (Gubernur atau Bupati) atau Badan Pertanahan Daerah dalam rangka meninjau kelancaran dan efesiensi waktu. Tidak hanya itu, keberhakan dalam mendapat izin Pemerintah Daerah lebih mengetahui secara lokal sesuai konkrit.

c. Kewenangan Pengadaan Tanah Untuk Kepentingan Umum Hanya Ada Pada Pemerintah Pusat Dan Daerah Provinsi

Kewenangan ini telah disebutkan sebelumnya dalam Peraturan Presiden No 148 Tahun 2015 tentang Pengadaan Tanah Bagi Pembangunan Kepentingan Umum. Sesuai peraturan tersebut, wewenang dalam rangka pembangunan tersebut berkerjasama dengan Gubernur dalam membentuk tim perencanaan, pendataan awal lokasi dan konsultasi publik tentang rencana pembangunan. 
Selain itu, tim yang dibentuk oleh gubernur untuk membantu gubernur melaksanakan inventarisasi masalah yang menjadi alasan keberatan, melakukan pertemuan atau klarifikasi dengan pihak yang keberatan, melakukan kajian dan membuat rekomendasi diterima atau ditolaknya keberatan tersebut. Maka hubungan kerjasama tersebut merupakan satuan tugas bersama Menteri untuk menjalankan pengadaan Tanah.

Apabila dikaitkan dengan fungsi yang dijalankan oleh BPN dalam melaksanakan tugas di bidang pertanahan sebagaimana diatur dalam Peraturan Presiden No 20 Tahun 2015 maka ruang lingkup urusan pertanahan yang diatur dalam Undang-Undang No 23 Tahun 2014 relatif lebih sempit dibandingkan dalam Peraturan Presiden 20 Tahun 2015. Didalam Peraturan Presiden 20 Tahun 2015 hanya menjelaskan fungsi dan tugas BPN sebagai Badan yang mengurus Pertanahan yang ada di Pusat dan di dearah masing-masing sesuai peraturan Perundangundangan. Tidak hanya itu, sumber pendanaanya dilimpahkan kepada APBN bukan APBD. Dapat dilihat dalam penjelasan beberapa pasal bahwa segala tugas dan wewenang Kepala Badan Pertanahan Daerah harus disesuaikan dengan unit atasannya. Dengan demikian maka pelimpahan wewenang untuk melaksanakan hak penguasaan dari negara atas tanah itu adalah merupakan medebewind. Segala sesuatunya akan diselenggarakan menurut keperluannya dan tidak boleh bertentangan dengan kepentingan nasional, dan wewenang dalam bidang agraria dapat merupakan sumber keuangan bagi daerah itu. 


\section{PENUTUP}

Berdasarkan hasil analisis penulis, maka hubungan pemerintah daerah dengan pemerintah pusat adalah:

a. Bahwa dalam UU No 23 Tahun 2014 pula terdapat (3) sub pengurusan tanah yang tidak ada kewenangannnya pada pemerintah pusat adalah urusan tanah ulayat, tanah kosong dan penerbitan izin.

b. Bahwa berdasarkan kajian Hukum Administrasi Negara urusan perizinan dalam menguruskan tanah dilimpahkan kepada pemerintah Kabupaten (Gubernur atau Bupati) atau Badan Pertanahan Daerah dalam rangka meninjau kelancaran dan efesiensi waktu

c. Bahwa apabila dikaitkan dengan fungsi yang dijalankan oleh BPN dalam melaksanakan tugas di bidang pertanahan sebagaimana diatur dalam Peraturan Presiden No 20 Tahun 2015 tentang Badan Pertanahan Nasioanl, maka ruang lingkup urusan pertanahan yang diatur dalam Undang-Undang No 23 Tahun 2014 relatif lebih sempit dibandingkan dalam Peraturan Presiden 20 Tahun 2015 tengan BPN. 


\section{DAFTAR PUSTAKA}

UU Nomor 23 Tahun 2014 tentang Pemerintahan Daerah

Undang-Undang Pokok Agraria Undang-Undang No.5 Tahun 1960 (UUPA)

Peraturan Presiden 20 Tahun 2015 tentang Badan Pertanahan Nasional

Peraturan Presiden No 148 Tahun 2015 tentang Pengadaan Tanah Bagi Pembangunan Kepentingan Umum

Anggriani , Jum, Hukum Administrasi Negara, Yogyakarta : Graha Ilmu, 2012.

Asshiddiqie, Jimly, Perihal Undang-Undang (Jakarta: Rajawali Pres, 2011.

Ilyas dkk, Kewenangan Pemerintah Daerah dalam Menyelesaikan Sengketa Tanah dalam Jurnal Ilmu Hukum No.65 April 2015.

Justitia, Fiat, Pengisian Jabatan Gubernur di Indonesia dalam Jurnal Ilmu Hukum Volume 6 No. 1 Januari-April 2012.

Kaho ,Riwu, Analisis Hubungan Pemerintah Pusat dan Daerah di Indonesia, Yogyakarta: Pol Gov Fisipol UGM, 2012.

M.Hadjon, Philipus dkk, Pengantar Hukum Administrasi Indonesia, Yogyakarta: Gajah Mada University Press, 2015.

Ridwan HR, Hukum Administrasi Negara,(Jakarta: Rajawali Pers, 2016.

Said, Abdul Rauf Alaudin, Pembagian Kewewenangan Pemerintah Pusat dan Daerah Dalam Otonomi yang Seluas-Luasnya Menurut UUD 1945 dalam Jurnal Ilmu Hukum Vol. 9 No. 4, Oktober-Desember 2015.

Simamora, Janpatar, Problema Penyelesaian Sengketa Lembaga Antar Negara Oleh Mahkamah Konstitusi dalam Jurnal Mimbar Hukum, Vol. 26 Nomor 1, Februari 2016.

Solihat, Yeyet, Hukum Agreria Nasional dalam Majalah Ilmiah Solusi Unsika ISSN 1412-86676 Vol. 10 No. 22 Ed. Mar - Mei 2012. 